\title{
6
}

\section{A POLISSEMIA DE VÍRUS DOS OITOCENTOS AO TEMPO DO NOVO CORONAVÍRUS: UM ESTUDO SOB A PERSPECTIVA DA SEMÂNTICA COGNITIVA SÓCIO- HISTÓRICA}

\section{THE VIRUS POLYSEMY FROM THE EIGHT HUNDRED TO THE TIME OF NEW CORONAVIRUS: A STUDY FROM THE PERSPECTIVE OF COGNITIVE SOCIO-HISTORICAL SEMANTICS}

\author{
Elisângela Santana dos Santos ${ }^{1}$ \\ Universidade do Estado da Bahia
}

\begin{abstract}
Resumo: Apresentam-se os resultados de um estudo sobre a polissemia de vírus no português brasileiro escrito, a partir de um corpus constituído por textos dos séculos XIX e XX, que constam da Linguateca, e de textos da Internet, produzidos ao longo dos últimos meses do século XXI, durante a pandemia do novo coronavírus. Para isso, foi feito um estudo descritivo-interpretativo, respaldado em princípios e linhas de investigação da Semântica Cognitiva Sócio-Histórica. Como resultado preliminar, concluiu-se que o sentido relativo ao domínio da Biologia/Ciências da Saúde é o mais prototípico e serve de base conceptual para formação de novos sentidos, os quais se inter-relacionam por via metafórica e/ou imago-esquemática.
\end{abstract}

Palavras-chave: Polissemia; Vírus; Conceptualização; Categorização.

Abstract: The results of a study about polysemy of virus in written Brazilian Portuguese, based on a corpus made up of texts from the 19th and 20th centuries that appear in the Linguateca and texts from the Internet, produced over the last months of the 21st century, during the pandemic of the new coronavirus. For this, a descriptive-interpretative study was carried out, supported by principles and lines of investigation of

${ }^{1}$ Endereço eletrônico: elisangelasantana2008@gmail.com 
Cognitive Socio-Historical Semantics. As a preliminary result, it was concluded that the meaning related to the domain of Biology / Health Sciences is the most prototypical and serves as a conceptual basis for the formation of new meanings, which are interrelated through metaphorical and / or imago-schematic ways.

Keywords: Polysemy, Virus, Conceptualization, Categorization.

\section{ALGUMAS CONSIDERAÇÕES INICIAIS}

Em meio à pandemia de COVID-19 que se propagou nos diferentes continentes e países do globo terrestre, acometendo e provocando a morte de inúmeras pessoas, percebi que o emprego do item lexical vírus tem sido bastante recorrente no português brasileiro, tanto na oralidade quanto na escrita. Não sem motivo, tal incidência foi alavancada pela proliferação de um vírus altamente contagioso e letal, sobre o qual cientistas do mundo inteiro se debruçaram a estudar, uma vez que quase nada sabiam a respeito dele. Seu nome científico Sars-CoV-2, também conhecido como novo coronavírus devido à sua semelhança com uma coroa, passou a ser rapidamente propalado por toda a mídia.

Diante da presença indesejada de diversos vírus em diferentes populações e da recorrência do emprego dessa palavra centrada nos domínios da Biologia e das Ciências da Saúde, mas não necessariamente a ambos restrito, interessei-me por pesquisar não apenas quais ou quantos sentidos são acionados por esse item lexical e o quanto ele é polissêmico, mas o que a relação entre a sua rede de significação e a compreensão de mundo do ser humano nos revela sobre nossa maneira de pensar e de agir no devir da história.

Por se tratar de um estudo semântico em perspectiva cognitiva sóciohistórica, consultei o dicionário etimológico de Cunha (1986) e verifiquei que vírus remonta ao latim, 'virus', cujo significado era "veneno", "peçonha", o qual se mantém parcialmente perspectivado na designação dos diferentes patógenos 
virais causadores de inúmeras enfermidades que afetam a cadeia dos seres vivos há milênios ${ }^{2}$, podendo causar a destruição e até levar a óbito o ser contaminado.

A infecção por um vírus, portanto, é sentida na pele e vivenciada corporalmente pelos seres vivos como algo (mais ou menos) negativo, dependendo do tipo de agente infeccioso e do que ele causa. Essa experiência pode ser projetada inconscientemente para outros domínios do conhecimento humano menos corporificados, menos concretos, de tal modo que algumas situações que ocorrem na vida cotidiana, como a divulgação de memes, fofocas, fake news e ações perniciosas, que expressam algum tipo de informação, preconceito, injustiça social ou corrupção, por exemplo, podem ser conceptualizadas como virais, por se propagarem de maneira rápida, sem controle ou por trazerem efeitos indesejados ou danosos para algo ou alguém.

Nos últimos tempos, não tem sido difícil encontrar, em variados contextos e gêneros textuais, além do vírus da COVID, o emprego de expressões como vírus da preguiça, vírus da ignorância, vírus da corrupção, entre outras, e também palavras derivadas, como o adjetivo viral e o verbo viralizar, conforme já mencionado. Ademais, com os avanços tecnológicos e o surgimento da Internet, passaram a ser constantes as menções aos malwares ou softwares perniciosos, conhecidos como vírus de computador, por invadirem, infectarem e até destruírem sistemas computacionais e/ou operacionais diversos, causando desde pequenos problemas a prejuízos imensuráveis aos afetados. A partir dessas projeções ou mapeamentos são geradas extensões de sentido que se associam às referidas expressões.

\footnotetext{
2 Na matéria intitulada Vírus: vida e obra do mais intrigante dos seres, publicado na Revista Superinteressante, datada de março de 2020, seu autor informa que uma das várias hipóteses para a origem dos vírus é de que eles seriam ex-bactérias que se tornaram cada vez mais rudimentares. Isso teria acontecido há bilhões de anos. Disponível em: https://super.abril.com.br/especiais/virus-vida-e-obra-do-mais-intrigante-dos-seres/ Acesso em: 10 nov. 2020.
} 
Portanto, diante da ampla rede de significação que o item lexical vírus pode assumir, busco trazer, neste trabalho, alguns resultados de um estudo ainda inicial sobre essa temática. Para isso, pesquisei, neste primeiro momento, textos escritos nos séculos XIX, XX e XXI, disponíveis em corpora digitais da Linguateca, e alguns textos do século XXI, produzidos e publicados na Internet durante o primeiro ano da pandemia do novo coronavírus.

Por considerar que projeções metafóricas e imago-esquemáticas podem agir como propulsoras da polissemia desse e de outros itens lexicais, conforme já pude constatar ao estudar a natureza polissêmica de alguns nomes e verbos da língua portuguesa, pautei-me nos pressupostos teórico-metodológicos da Semântica Cognitiva Sócio-histórica, uma das vertentes da Linguística Cognitiva (doravante, LC), que tem servido como base para os estudos que venho desenvolvendo. Trata-se de uma abordagem semantocêntrica que entende o significado linguístico como perspectivista, enciclopédico, flexível, corporificado, baseado no uso e, portanto, resultante da conceptualização e da categorização humana.

Para dar conta da discussão proposta, utilizei como aporte teórico os textos de autores como Lakoff e Johnson (1980), Geeraerts (2006), Silva (2004, 2006), Almeida (2020), Almeida e Santana (2019), Almeida e Santos (2019), Batoréo (2009), Fernandez Jaén (2014), Teixeira (2005), entre outros. Para o tratamento do corpus, adotei a metodologia qualitativa e propus uma abordagem documental, descritiva e interpretativa do fenômeno estudado. Por último, para apresentar os resultados alcançados, a partir do desenvolvimento da pesquisa, organizei o texto em três seções que se seguem, além destas Palavras Iniciais, das Considerações Finais e das Referências. Na sequência, passo a discorrer sobre a base teórica que sustentou os estudos aqui expostos. 


\section{A POLISSEMIA SOB O ENFOQUE DA SEMÂNTICA SÓCIO- HISTÓRICO-COGNITIVA}

Buscar entender como ocorre a construção do significado e sua relevância para a linguagem é uma inquietação que remonta a um passado distante. Embora já existissem especulações nos períodos antigo e medieval acerca dos múltiplos sentidos que uma palavra pode acionar em um determinado contexto, essa preocupação ganhou maior destaque no século XIX, mais precisamente em 1897, quando o linguista francês Michel Bréal publicou o livro Essai de Sémantique, Science des Significations, traduzido para o português como Ensaio de Semântica: ciência das significações, e cunhou a palavra de origem grega, polissemia, que, costuma ser definida, em linhas gerais, como a capacidade de atribuir a um item lexical múltiplos sentidos relacionados entre si e uma origem comum.

Mesmo não recebendo muita atenção dos representantes das principais correntes teóricas da Linguística na primeira metade do século $\mathrm{XX}$, a polissemia não deixou de ser abordada, tendo experimentado diferentes tratamentos. As teorias linguísticas que se sobressaíram, nesse período, mais particularmente, o Estruturalismo saussureano e o Gerativismo chomskiano, ao definirem postulados teóricos e pressupostos metodológicos em conformidade com a perspectiva formal, viam o conhecimento linguístico dissociado do conhecimento enciclopédico, o que reforçava a ideia da linguagem como entidade autônoma e do significado como um constructo mental, já que a mente era vista como uma parte não integrada ao corpo e os conceitos desembodied, isto é, não corporizados, tal como designou Johnson (1987). Essa forma de entender as questões semânticas com foco em uma visão mentalista autonomista preponderou entre as décadas de 1950 e 1960 e caracterizou a "primeira onda cognitivista".

Todavia, em fins dos anos 1970 e início dos anos 1980, Lakoff (1987), Langacker (1987) e Talmy (1983), entre outros dissidentes do Gerativismo, iniciaram um movimento em favor de uma nova proposta teórica, a LC, que tinha 
como objetivo precípuo contestar o mentalismo até então vigente, mostrando ser inviável proceder ao estudo linguístico sem considerar a Semântica, assim como a historicidade e a corporeidade da linguagem.

Esse novo modelo teórico foi denominado inicialmente de Semântica Gerativa, o qual, mais tarde, originou a Semântica Cognitiva, que se contrapôs aos estudos formalistas. Seu principal objetivo, dentre outros, era tratar o funcionamento da linguagem como algo intrinsecamente ligado à cognição e à experiência humana (tanto física como social); tal princípio está na base dos estudos semânticos voltados, principalmente, para a compreensão do que é a polissemia. Portanto, embates entre essas diferentes teorias do conhecimento e suas respectivas visões antagônicas sobre a inter-relação entre corpo, mente, significado e cognição propiciaram o surgimento de uma nova fase para os estudos semânticos, conhecida como a "segunda onda cognitivista", que retomou a concepção de significado prenunciada quase um século antes.

Em meio a essa reconfiguração teórico-metodológica, a polissemia tornase um dos temas centrais da nova abordagem que surge, assim como a metáfora, a metonímia e outros fenômenos semânticos e também cognitivos averiguados pelas diferentes linhas de investigação que compõem o arquipélago dos estudos cognitivistas da linguagem. Entre as diferentes ilhas teóricas que o integram e compartilham da mesma concepção de mente corporificada atrelada a uma cognição situada e ao significado experiencial, destaco a Semântica Cognitiva Sócio-histórica, a Teoria da Metáfora Conceptual, a Teoria dos Protótipos e a Teoria dos Esquemas de Imagens, por alicerçarem o estudo, cujos resultados estão, aqui, apresentados.

Diante disso, é possível afirmar que, ao pesquisar a polissemia de vírus em perspectiva Semântica Cognitiva Sócio-histórica, busquei evidenciar o entendimento de que as capacidades e mecanismos cognitivos humanos estão intrinsecamente envolvidos no processo de construção de sentidos e no uso de diferentes linguagens como manifestação do pensamento ao longo do tempo. 
Embora para alguns linguistas, o fenômeno da polissemia seja considerado um tipo de ambiguidade lexical, conforme descreve Cançado (2008), para quem o estuda, segundo uma perspectiva cognitiva sócio-histórica, prevalece a compreensão de que o significado não está simplesmente nas palavras e expressões, uma vez que se constrói na interação do sujeito conceptualizadorcategorizador com o meio, com os seres, com o texto, emergindo, portanto, do contexto geo-sócio-histórico-cultural-político-ideológico, tal como definiram Almeida e Santana (2019), bem como Almeida e Santos (2019).

Essas conexões entre os seres humanos e o mundo manifestam-se na construção dos significados por meio de operações cognitivas que envolvem perspectivações, categorizações e conceptualizações metafóricas e metonímicas de base esquemo-imagética que são propulsoras de polissemia. Para melhor entendê-las, passo a discorrer sucintamente sobre os fenômenos da categorização e da conceptualização e suas imbricações com as teorias cognitivas que embasam o estudo do corpus que apresento na sequência.

\section{CATEGORIZAÇÃO, CONCEPTUALIZAÇÃO E POLISSEMIA}

Os estudos semânticos sob o escopo da Linguística Cognitiva preconizados por Lakoff e Johnson (1980, 2002, p. 218) evidenciam que a categorização e a conceptualização são mecanismos cognitivos intrinsecamente atrelados à linguagem, sendo a polissemia um fenômeno semântico resultante desses dois processos. Ao relacionar-se físico-espacialmente e articular-se sóciohistoricamente e intelectualmente, o ser humano está sempre categorizando e conceptualizando.

Categorizações e conceptualizações por meio de metáforas e transposições de esquemas de imagens estão na base de variações e mudanças dos significados do léxico. Para discorrer sobre categorização, é oportuno abordar algumas questões relativas à Teoria do Protótipo. A discussão sobre protótipos e 
prototipicidade tem sido aplicada aos estudos da polissemia, porque as unidades polissêmicas são entendidas como categorias radiais que se inter-relacionam, podendo interconectar-se direta ou indiretamente com um membro mais saliente conceptualmente, considerado prototípico, o qual pode variar a depender do contexto sócio-histórico. Essas relações não são estáticas e podem alterar-se, desaparecer ou multiplicar-se em uma mesma sincronia ou em sincronias distintas, uma vez que a linguagem é dinâmica.

Esses processos de variação e mudança de sentidos refletem não apenas a dinamicidade da língua portuguesa, como também o fato de o ser humano (re)categorizar e (re)conceptualizar novas experiências em termos de outras já conhecidas e vivenciadas, que passam a ser entendidas através de uma nova perspectiva. Embora o sentido novo tanto possa aproximar-se quanto afastar-se de outro sentido acionado anteriormente, tornando-se mais saliente conceptualmente ou mais periférico dentro de uma determinada categoria, o sentido antigo e/ou o sentido menos saliente não deixam de integrar a mesma categoria. Essa flexibilidade ocorre em um processo contínuo de geração e organização de novos conhecimentos elaborados pela humanidade, os quais se refletem nas formas de percepção das sociedades em diferentes momentos da sua história.

Em outras palavras, os processos de mudanças e de variação pragmáticosemântico-lexical-discursiva podem ser acumulativos, pois as formas e significados inovadores que surgem nem sempre excluem as formas e significados já existentes (ALMEIDA; SANTOS, 2019). Ao contrário de anularemse, não poucas vezes somam-se, inter-relacionam-se em uma rede de sentidos complexa, que pode revelar muito sobre a sociedade e seus valores, suas crenças, suas práticas sociais, suas formas de pensar e existir, evidenciando suas conceptualizações.

As conceptualizações realizadas na e através da linguagem apoiam-se em uma base experiencial, uma vez que estão relacionadas com a maneira como a 
realidade é experimentada, tanto fisiológica como sócio-histórica e culturalmente. Para uma análise semântica conceptualista, quem está pesquisando procura levar em conta os usos linguísticos, que, por sua vez, refletem experiências perceptuais, sensações e projeções conceptuais, por meio de metaforizações, responsáveis pela formulação de conceitos (LANGACKER, 2007). Essa relação, por sua vez, ocorre através de projeções entre domínios de experiência, também conhecidas como mapping ou mapeamentos.

O mapeamento metafórico, recorrente nos casos de polissemia, estabelece uma relação de similaridade e interação entre um domínio-fonte, considerado mais conhecido, por ser experienciado físico-espacial e sócio-culturalmente, e um domínio-alvo, menos conhecido e, em alguns casos, mais abstrato. Sardinha (2007), ao definir as metáforas como um instrumento para criar um novo conhecimento ou para dar conta de algo novo na ciência ou no cotidiano, dá o exemplo da expressão janelas do computador, que surgiu quando os sistemas computacionais passaram a dispor de recursos e as partes da tela do computador passaram a mostrar os programas computacionais, não sendo aleatória, portanto, a nomeação do sistema operacional Windows. Em outras palavras, o domínioalvo, o novo, relativo aos programas computacionais que se abriam na tela, foi conceptualizado em termos do domínio-fonte, as janelas, mais próximo da experiência física humana. Esse é um caso típico de polissemia resultante de uma conceptualização metafórica que se convencionalizou.

O uso inconsciente de metáforas possibilita que um conceito possa ser compreendido parcialmente em termos de outro, uma vez que nem todos os elementos de um domínio-fonte são projetados ou perspectivados no domínioalvo, como defendem Almeida e Santos (2020), Barcelona (2003) e Paiva (2010). Esse mapeamento pode ser representado por uma notação expressa da seguinte maneira: X É (PARCIALMENTE) Y³ , ou DOMÍNIO- ALVO É (PARCIALMENTE)

\footnotetext{
${ }^{3} \mathrm{O}$ uso da caixa alta para representar a notação que contém a metáfora conceptual é uma convenção empregada pelos pesquisadores da Linguística Cognitiva.
} 
DOMÍNIO-FONTE, de modo que é possível depreender, considerando o exemplo anterior, que a metáfora conceptual que alicerça algumas expressões linguísticas relativas à área da computação pode ser descrita como SISTEMAS OPERACIONAIS NA TELA DO COMPUTADOR SÃO JANELAS.

Em linhas gerais, é possível notar que essas conceptualizações metafóricas ocorrem a partir de transposições de esquemas imagéticos, que atuam como princípios estruturantes de todo e qualquer processo de conceptualização. (OAKLEY, 2007, p. 218). Dentre os vários esquemas existentes, interessam a este trabalho apenas o esquema denominado por Lakoff (1987) de origem-percursometa, também chamado de trajector, de acordo com a terminologia de Langacker (1991), o qual envolve um grande número de atividades humanas; o esquema do contato, mencionado por Johnson (1987) e por Hampe (2005); o esquema da força dinâmica, posto por Talmy (1988), e o esquema do continente/conteúdo ou container, nomeado também como recipiente por Lakoff e Johnson (2002).

Esses esquemas, segundo Johnson (1987), aparecem regularmente no pensamento, no raciocínio e na imaginação das pessoas, e embasam o conhecimento e os significados fundamentais construídos pelos seres humanos, por estarem atrelados às suas atividades sensório-motoras mais simples, como movimentar-se dentro e fora de um espaço ou imprimir algum tipo de força em uma determinada ação. É importante salientar, entretanto, que o esquema não é uma imagem real, concreta ou uma pintura mental. Como adverte Lakoff (1987), a imagem não se limita ao campo da visão e, por conseguinte, não é uma menção meramente pictórica. Trata-se de uma estrutura esquemática, não proposicional, que não se refere a uma representação semântica específica nem a uma imagem estática, pois surge diretamente da experiência corpórea com o mundo, refletindo-se na linguagem.

Ao estudar a multiplicidade de sentidos do item lexical vírus em um corpus de língua escrita, considerando a perspectiva da Semântica Cognitiva Sócio-histórico, é possível perceber alguns desses esquemas embasando, 
estruturando os sentidos que são construídos. Quando, por exemplo, vírus é acionado como software malicioso que ataca sistemas operacionais ou computacionais é possível depreender a metáfora SOFTWARE MALICIOSO É VÍRUS e, por conseguinte, os esquemas origem-percurso-meta, recipiente, força e contato, não mais no domínio físico, mas no domínio virtual.

Dito de outro modo, tal conceptualização metafórica aciona os mesmos esquemas de imagem presentes na compreensão que o ser humano tem sobre um contágio viral provocado por um microrganismo que atua de fora para dentro do seu corpo, já que um vírus de computador, ao adentrar um sistema operacional de uma máquina, tal como o vírus COVID-19 ou qualquer outra infecção viral que acometa o organismo humano, seu hospedeiro, ali se instala, estabelecendo um contato que, por sua vez, gera uma dinâmica de força, na medida em que, assim como o ser humano tenta combatê-lo usando medicamentos ou vacinas, o programador ou o usuário do computador instala softwares antivirais nos sistemas operacionais.

Enfim, após tratar dos aspectos teóricos que norteiam o estudo do significado linguístico em uma perspectiva cognitiva-sócio-histórica, passo a discorrer sobre questões de natureza metodológica.

\section{O PERCURSO METODOLÓGICO ADOTADO PARA O ESTUDO DA POLISSEMIA DE VÍRUS}

O percurso ora apresentado envolveu diferentes etapas. Antes de perquirir o corpus constituído para pesquisa, com vistas à apresentação dos resultados que faço a seguir, realizei, como já anteriormente mencionado, uma busca inicial ao dicionário etimológico de Cunha (1986) para conhecer a origem da palavra vírus, uma vez que se trata de um estudo científico léxico-semântico de caráter cognitivo sócio-histórico. Na sequência, busquei dicionários de séculos passados e do século atual. Só depois dessa etapa, debrucei-me nas ocorrências extraídas da Internet que traziam matérias ou artigos científicos do século XXI, 
para então cotejar os dados encontrados com textos escritos em outros momentos da história da língua portuguesa, mais especificamente nos séculos XIX e XX, os quais foram extraídos de diferentes corpora da Linguateca ${ }^{4}$.

Por serem recorrentes os contextos em que vírus aparece conceptualizado como um organismo infectocontagioso nos textos em que pesquisei, fiz um recorte que descrevo a seguir, apoiada na Técnica da Saturação, defendida por Almeida (2020) como um meio para realizar estudos semânticos cognitivos sóciohistóricos com base em corpora, e aplicada por Santana (2019) em sua tese de Doutorado, quando estudou a conceptualização de amor em cartas trocadas por casais. Trata-se de uma perspectiva empregada em várias áreas do saber que se centra na qualidade e não na quantidade dos dados a serem coletados e analisados. Foi escolhida para aplicação neste trabalho, por ser perceptível a recorrência de um mesmo padrão de usos nos textos que compõem o corpus constituído.

Sendo assim, ao verificar que havia usos e sentidos que se repetiam nos primeiros cinquenta textos, selecionei apenas quatro, considerando a Técnica da Saturação Teórica. São eles: Vírus: vida e obra do mais intrigante dos seres, escrito por Samuel Azevedo e publicado, em meio digital, em 13 de abril de 20205; O vírus da corrupção, artigo escrito por João Campos, deputado federal pelo

\footnotetext{
${ }^{4}$ A Linguateca constitui-se como um centro de recursos para o processamento computacional da língua portuguesa, o qual é operacionalizado através de um projeto coordenado e executado pela Fundação para a Computação Científica Nacional. Foi financiado por vários órgãos, tendo iniciado entre os anos de 1998-2000, expandindo-se depois para um projeto em rede. Seu objetivo é servir à comunidade que se dedica e se interessa pelo processamento computacional da língua. Esse projeto torna públicas todas as atividades e trabalhos realizados por seus pesquisadores, disponibilizando-os gratuitamente, por meio da Internet, em um portal constantemente atualizado, que dá acesso a um conjunto de recursos para o estudo da língua portuguesa e a vários corpora com características específicas, como tipo de texto, número de palavras, fontes, instituições criadoras e financiadoras. Disponível em: https://www.linguateca.pt/acesso/corpus.php?corpus=CBRAS Acesso em: 10 nov. 2020.

5 Disponível em: https://www.fatonews.com.br/virus-vida-e-obra-do-mais-intrigante-dosseres/ Acesso em: 11 nov. 2020.
} 
Republicanos Goiás e publicado, em 08 de julho de 2020, no Jornal Estadão6; Vírus de computador, escrito por Anna Adami e disponível no site da InfoEscola7, no ano de 2020, e O vírus da corrupção, escrito por Valdizar Andrade e publicado, em 23 de abril de 2020, na página do seu $\mathrm{Blog}^{8}$.

Procedimento semelhante adotei em relação ao AC/DC - Corpus Brasileiro disponibilizado pela Linguateca, que foi utilizado para o estudo que abarcou textos dos séculos XIX, XX e, também, XXI. Esse corpus reúne uma série de recursos que possibilitam trabalhar com o material exposto, permitindo o acesso a diferentes ferramentas e a textos orais e escritos em português europeu e brasileiro, em que as ocorrências podem ser encontradas por concordâncias, distribuição, frequências simples e complexas. Para a pesquisa que culminou na apresentação destes resultados, entretanto, só interessaram os textos escritos em português brasileiro. Após buscar a palavra vírus em textos dos corpora selecionados e, mais uma vez, verificar a recorrência da significação atrelada ao domínio da Biologia e das Ciências da Saúde, selecionei apenas três corpora referentes a textos do português brasileiro escritos nos séculos XIX, XX e XXI, que continham uma maior diversidade de sentidos, a saber: $D H B B$, Frases do PB e OBras.

O primeiro é o $D H B B$, o corpus dos Dicionários Históricos Brasileiros. Nele, estão contidas três obras de referência concebidas pelo Centro de Pesquisa e Documentação de História Contemporânea do Brasil da Fundação Getúlio Vargas (CPDOC/FGV): (1) o Dicionário histórico-biográfico da Primeira República (DHBPR), com dados sobre o período que vai da Proclamação da República, em 1889, até a Revolução de 1930; (2) o Dicionário Histórico-Biográfico Brasileiro

6 Disponível em: https://politica.estadao.com.br/blogs/fausto-macedo/o-virus-da-corrupcao/ Acesso em: 11 nov. 2020.

7 Disponível em: https://www.infoescola.com/informatica/virus-de-computador/ Acesso: 11 nov. 2020.

${ }^{8}$ Disponível em: https://valdizarandrade.com.br/o-virus-da-corrupcao/ Acesso em: 11 nov. 2020. 
(DHBB), sobre o período pós-1930 até os dias atuais; e (3) o Dicionário da política republicana do Rio de Janeiro (DPRRJ), sobre a história do estado e da cidade do Rio de Janeiro desde a Proclamação da República. Já o corpus FrasesPB é um conjunto de frases em português brasileiro e o corpus OBras (Obras Brasileiras) é um corpo de textos literários brasileiros escritos entre os séculos XIX e XX, que já alcançaram o domínio público.

A questão crucial que norteou o trabalho consistiu em identificar que mecanismos conceptuais estão na base da polissemia de vírus, com vistas a mostrar como isso se manifesta nos textos pesquisados concernentes aos três períodos e entender o que os resultados revelam sobre a compreensão humana dessa palavra plurissignificativa.

Ao perscrutar as obras lexicográficas dos séculos XX e XXI, diferente do que está documentado em dicionários do século XIX, observei que a lexia vírus apresenta uma rede de sentidos diversificada, o que atesta a sua polissemia no português brasileiro contemporâneo. Em Aurélio Online (2020) ${ }^{9}$, Aulete Digital $(2020)^{10}$, Michaelis (2020) ${ }^{11}$ e Houaiss $(2020)^{12}$, assim como no Priberam (2020) ${ }^{13}$, estão registradas diferentes acepções para a palavra vírus. Há, no mínimo, dois e, no máximo, seis sentidos para vírus nos verbetes das cinco obras consultadas; em todas, a primeira definição refere-se ao domínio da Biologia e das Ciências da Saúde, o que parece indicar que esse é o seu sentido mais prototípico desde o século $X X$ até a atualidade. Entretanto, nas referidas obras, também há menção

9 Disponível em Aurélio, Dicionário Online. Dicionário Online https://www.dicio.com.br Acesso em: 15 out. $2020 .{ }^{9}$

${ }^{10}$ Dicionário Aulete Digital. Disponível: http://www.aulete.com.br Acesso em: 15 Out. 2020.

11 Dicionário Brasileiro da Lingua Portuguesa. Disponível em: https://michaelis.uol.com.br/ Acesso em: 15 out. 2020.

12 Grande Dicionário Houaiss. Disponível em: https://houaiss.uol.com.br/corporativo/apps/uol_www/v5-4/html/index.php\#2 Acesso em: 17 nov. 2020.

13 Dicionário Priberam da Língua Portuguesa [em linha], 2008-2020. Disponível em: http://www.priberam.pt/dlpo/chave. Acesso em: 10 nov. 2020. 
ao domínio Tecnológico-computacional, o que é indicativo de um processo de conceptualização já assimilada pela sociedade brasileira contemporânea.

Em quatro dessas obras, há referência a vírus como mal ou perversidade de natureza moral que pode ser patológica e contagiar metaforicamente, mas nem todas dão exemplos. Apenas no Dicionário Online, de Aurélio (2020), aparece “o vírus da preguiça" e, no Priberiam (2020), do Brasil, o "vírus do preconceito racial". Também, apenas em Houaiss (2020), aparece o registro de "matéria que intoxica o corpo como veneno", remontando ao sentido etimológico. Uma outra observação interessante é o fato de que, excetuando o Priberiam (2020), as obras de Aurélio (2020), Houaiss (2020), Michaellis (2020) e Priberiam (2020) trazem os sentidos novos e mais abstratos categorizados como figurados (Fig.), e como informal (Inf.) na obra de Aulete (2020). Em todas, é possível identificar o registro de um alargamento semântico provavelmente motivado pelo surgimento de alguma noção que antes não existia ou que não foi registrada pelos lexicógrafos dos séculos anteriores.

Para melhor verificar se, no uso corrente da língua escrita nos séculos escolhidos para o trabalho ora apresentado, essas acepções se mantêm, se modificam ou desaparecem, coincidindo ou não com o que foi registrado nas obras lexicográficas consultadas, apresento, na seção a seguir, as ocorrências encontradas nos textos que constituíram o corpus da pesquisa realizada.

\section{O QUE OS TEXTOS DOS SÉCULOS XIX, XX E XXI NOS REVELAM SOBRE A POLISSEMIA DE VÍRUS}

Com base no que já foi exposto até aqui, é possível afirmar que os diferentes sentidos que compõem a rede semasiológica do item léxico vírus emergem de conhecimentos da experiência humana relativos a infecções patológicas virais causadoras de enfermidades que se manifestam no corpo físico. A rede polissêmica dessa palavra, portanto, não é resultado da mera soma 
de seus sentidos, mas se constitui a partir de conexões semântico-conceptuais atinentes a projeções metafóricas e esquemo-imagéticas.

Ainda que determinados sentidos de vírus derivados por via metafórica tenham sido detectados e, em sua maioria, estejam registrados tanto nas obras lexicográficas quanto nos textos dos séculos estudados, a acepção de vírus como organismo infectocontagioso prepondera não apenas nos textos circunscritos ao contexto da pandemia do novo coronavírus, mas em outros períodos e contextos em que há menção a surtos de vírus que existiram em algum momento da história da humanidade, evidenciando a prevalência de sentidos atrelados ao domínio da Biologia e das Ciências da Saúde.

No entanto, vale considerar que a frequência da acepção de vírus como software malicioso, identificada por meio de uma busca rápida na Internet e em quase todos os verbetes de dicionários da língua portuguesa por mim consultados, deve-se, provavelmente, à revolução tecnológica dos últimos tempos e parece confirmar não só a corporificação do significado linguístico e o reflexo dos avanços sócio-histórico-culturais na linguagem, mas, principalmente, a convencionalização desse uso metafórico no português contemporâneo, tal como é possível constatar nos exemplos (1) e (2) a seguir transcritos:

(1) [...] A solução para esses Tierras preguiçosos é parasitar Tierras inocentes, pegando linhas emprestadas para se reproduzir. Assim, às custas dos outros, eles se multiplicam. O nome disso é vírus. De computador, nesse caso. [....] Essa é uma de várias hipóteses para a origem dos vírus: eles seriam ex-bactérias que se tornaram cada vez mais rudimentares. (AZEVEDO, 2020) ${ }^{14}$.

(2) Odiado por todos, o Vírus de Computador é o inimigo número um de todos que possuem um desktop, notebook, tablet e até mesmo smartphone. Sua construção é simples mas pode ser devastadora. O Vírus é um software desenvolvido com base em características diversas e com inúmeros "temas". É chamado por muitos de software malicioso, tal qual um vírus que infecta o

14 Esse excerto foi extraído do texto Vírus: vida e obra do mais intrigante dos seres em: https://www.fatonews.com.br/virus-vida-e-obra-do-mais-intrigante-dos-seres/ Acesso em: 11 nov. 2020 
sistema e se espalha para outros computadores de forma muito rápida, através de links, e-mails e arquivos infectados. [...]. (ADAMI, s/d) ${ }^{15}$.

A partir dos sentidos identificados nesses exemplos, depreendi que o domínio-alvo (MALWARE), aquele menos conhecido, é entendido em termos do domínio-fonte, corporalmente conhecido e experienciado (VÍRUS), de modo que é possível inferir a metáfora MALWARE É VÍRUS, que se ancora nos esquemas imagéticos do origem-percurso-meta, pelo deslocamento que realiza; da força, por ser invasivo; do contato e do recipiente, por estabelecer um movimento de aproximação entre o meio externo e a máquina contaminada.

O mesmo padrão conceptual se repete nos exemplos (3) e (4), a seguir expostos, em que está subjacente a metafóra CORRUPÇÃO É VÍRUS, que importa, parcialmente, a estrutura conceptual do domínio da Biologia e das Ciências da Saúde. Nesses casos, comportamentos e valores morais nocivos, como corrupção (domínio-alvo), podem afetar pessoas individualmente ou a própria sociedade, sendo, portanto, perspectivados como um vírus (domíniofonte):

(3) O vírus da corrupção atinge a todos, mas as principais vítimas são aquelas que mais dependem dos recursos públicos. [...]. Para este mal existem vacinas, mas - assim como tantos outros vírus- é passível de mutações. [...] (CAMPOS, 2020). ${ }^{16}$

(4) Mas o pior de todos os vírus chama-se corrupção, esse a ciência não consegue desenvolver vacina, os pesquisadores não colocam a mão [...]. Muitos serão vítimas do Corona, mas antes foram vítimas da CORRUPÇÃO, [...]. (ANDRADE, 2020) ${ }^{17}$.

\footnotetext{
${ }^{15}$ Esse excerto foi extraído do texto Vírus de computador escrito por Ana Adami. Disponível em: https://www.infoescola.com/informatica/virus-de-computador/. Acesso em: 11 nov. 2020.

${ }^{16}$ Esse excerto foi extraído do texto $O$ vírus da corrupção, escrito por João Campos, deputado federal pelo Republicanos Goiás e publicado pelo Jornal Estadão, em 08/07/2020. Disponível em: https://politica.estadao.com.br/blogs/fausto-macedo/o-virus-da-corrupcao/ e, também, em:

https://republicanos10.org.br/republicanos-na-camara/o-virus-da-corrupcao/ Acesso em: 11 nov. 2020.

${ }^{17}$ Esse excerto foi extraído do texto O vírus da corrupção, escrito por Valdizar Andrade e publicado em 23 de abril de 2020. Disponível em: https://valdizarandrade.com.br/o-virus-da-corrupcao/ Acesso: 11 nov. 2020.
} 
É possível notar, por meio dos sentidos acionados em (1), (2), (3) e (4), que o conhecimento partilhado de vírus como um microrganismo infectocontagioso, que acomete os seres vivos, podendo causar-lhes prejuízos à saúde, foi projetado no domínio das Ciências da Computação e no domínio do Comportamento Social ou da Moralidade, gerando novos sentidos que se inter-relacionam e coexistem, respectivamente: vírus é um programa invasivo e prejudicial que se instala em um computador e vírus é mal moral que afeta as sociedades.

De modo semelhante ao que foi identificado nos excertos (1) e (2) extraídos de textos da Internet escritos no século XXI, também encontrei, no século XX, no corpus FrasesPB da Linguateca, a conceptualização MALWARE É VÍRUS, que, por sua vez, pressupõe a personificação de vírus e acarretamentos como vírus de computador é inimigo/software malicioso é inimigo, uma vez que ataca, invade, metaforicamente, o sistema computacional e pode danificar documentos arquivados digitalmente, conforme demonstrado em (5):

(5) par=585: Os documentos eram seguros contra os ataques dos vírus até poucos anos atrás, já que os documentos não continham nenhum código executável em si. (FRPB).

Essa significação evidencia, mais uma vez, uma marca da vida cultural da contemporaneidade, já que o sujeito conceptualizador-categorizador, ao acessar o domínio das Ciências da Computação, deixa pressuposta a vinculação entre metáfora e sociedade contemporânea. O mesmo sentido, obviamente, não poderia ser atestado no século XIX, uma vez que a revolução tecnológica só aconteceu a partir do século XX, depois do fim da Segunda Guerra Mundial, em 1945, quando surgiu o primeiro computador eletrônico de larga escala.

Partindo para o corpus do $D H B B$, que reúne textos escritos em finais do século XX e início do XXI, entre as 26 ocorrências de vírus encontradas, 14 remetem aos domínios prototípicos da Biologia e/ou das Ciências da Saúde; chama a atenção, entretanto, o fato de que o vírus ao qual os autores dos textos se 
referem, na maioria das vezes, é o da Aids, conforme é possível constatar em (6) e (7). Ao que parece, isso se deve ao período em que os textos do corpus foram escritos ou ao período a que se referem, como ilustram as transcrições a seguir:

(6) dhbb4909 : [...] que obrigou o Estado a, através do Serviço Único de Saúde (SUS), fornecer medicamentos para todos os cidadãos e cidadãs portadores do vírus da AIDS. (DHBB).

(7) dhbb658 : Três anos depois, em 1986, após ter descoberto que havia sido contaminado com o vírus da Aids numa transfusão de sangue, [...]. (DHBB).

Os demais trechos encontrados no $D H B B$ trazem, também, expressões metafóricas, como vírus do reformismo (8), vírus da descrença (9), vírus da Ditadura (10) e vírus da corrupção (11), os quais evidenciam comportamentos sociais, valores morais e formas de gestão malquistos e malvistos pela sociedade brasileira; por serem considerados maléficos e poderem se propagar em um determinado ambiente, causando prejuízos aos atingidos, são conceptualizados como contagiosos:

(8) dhbb1190: Posteriormente, Último de Carvalho passou a opor-se ao governo Goulart, por considerá-lo radical, tornando-se um dos mais candentes críticos da reforma agrária preconizada pelo presidente, alegando que era de inspiração comunista e que o vírus do reformismo atacara o palácio Alvorada. (DHBB).

(9) dhbb2210: Numa alusão velada à chamada «Igreja progressista», fez referência ao fato de que o marxismo -- «escondido sob as mais diferentes vestes, muitas das quais secularmente respeitadas» -- buscava inocular, principalmente na juventude, «o vírus da descrença, a luta de classes e a desmoralização dos líderes democráticos».(DHBB).

(10) dhbpr1499: Ao receber a informação de que muitos dos participantes da reunião já haviam aderido plenamente à perspectiva bolchevique, Oiticica retirou-se abalado com o que considerou uma «ação subterrânea» de Astrojildo, que teria «minado os sindicatos» e «propagado o vírus da ditadura do proletariado e da férrea disciplina». (DHBB).

(11) dhbb11394: Em outubro, Dom Antônio Celso denunciou o que chamou de «clima de corrupção» no Brasil, comparando a corrupção a «um vírus que vai se infiltrando e que devia ser combatido», também criticou os debates realizados entre os presidenciavéis [sic] Luís Inácio Lula da Silva, do PT e 
Geraldo Alckmin, do Partido da Social Democracia Brasileira (PSDB). (DHBB).

Como é possível ver em (11), a conceptualização de corrupção como vírus, no fragmento transcrito de um texto do início deste século, não difere do que foi encontrado em textos escritos mais recentemente, conforme atestam os excertos (3) e (4) já comentados.

Também, não são muito diferentes os sentidos de vírus identificados no século XIX, no corpus OBras, da Linguateca, que é composto por obras literárias brasileiras. Nos 14 trechos em que detectei a ocorrência do item lexical estudado, identifiquei apenas um contexto em que ocorre a acepção prototípica atrelada ao domínio da Biologia e das Ciências da Saúde, sendo as demais extensões desse sentido e, portanto, usos criativos que repetem o mesmo padrão das conceptualizações anteriores.

Os trechos dos romances O Cortiço, de Aluísio de Azevedo (1890), em (12), e A Partida, de Coelho Neto (1899), em (13), escritos em finais do século XIX, comprovam isso. Além de revelarem crenças, comportamentos sociais, valores morais e sentimentos dos sujeitos escreventes-conceptualizadorescategorizadores, trazem à tona temas recorrentes dos romances naturalistasrealistas, como a lascívia e a prostituição, dentre outros conteúdos estigmatizados e criticados pela sociedade brasileira na época, depreendendo-se daí a sua conceptualização como vírus:

(12) id="O_Cortiço Prosa:romance AA 1890 naturalismo masc ": Sim, lá os campos eram frios e melancólicos, de um verde alourado e quieto, e não ardentes e esmeraldinos e afogados em tanto sol e em tanto perfume como o deste inferno, onde em cada folha que se pisa há debaixo um réptil venenoso, como em cada flor que desabotoa e em cada moscardo que adeja há um vírus de lascívia. (OBras).

(13) id=" A_conquista Prosa:romance CN 1899 realismo masc ": Em Babilõnia havia, ao menos, um subúrbio sagrado onde avultava, entre cedros e loureiros, o templo de Mylitta, ainda assim o historiador clama contra a vergonha Que diria ele se, revivendo, viesse, tantos séculos depois, olhar $a$ prostituição que aqui transborda e vai invadindo, como um vírus, todas as artérias da cidade? (OBras). 
Alguns aspectos, porém, destacam a importância do estudo de corpus. Ainda que o significado etimológico de vírus se mantenha esmaecido na maioria das ocorrências encontradas, no excerto (14), registrado na obra Banzo, de Raimundo Correia, datada do início do século XX, o sentido originário reaparece:

(14) id="Banzo Prosa:contos CN 1912 realismo masc ": E a vida do vasto rebalso era animada pelo voo enxameado das moscas luzentes, das lavadiscas que esfuziavam, dos mangangás que zuniam, dos grandes besouros que passavam de arremesso e, não raro, o pium inflectia num bote de frecha, levando no ferrão o vírus que inflama e abre a carne em ferida. (OBras).

O emprego de vírus, nesse trecho, recupera parcialmente a noção de veneno que consta do seu étimo. Por meio do ferrão "dos grandes besouros", que também é comum em insetos como abelhas e vespas, a substância venenosa, viral, pode ser transmitida, vindo a causar danos a quem tiver sua carne atingida e ferida.

Também, chama a atenção o domínio-alvo dos sentimentos amor e ódio, em (15) e (16), respectivamente. Ambos herdam conceptualmente as estruturas imago-esquemáticas de origem-percurso-meta, da força, do contato e do recipiente relativos ao domínio-fonte da Biologia e das Ciências da Saúde e são compreendidos como organismos infectocontagiosos. Em (15), ao que parece, o amor, tão idealizado na prosa e na poesia românticas, é compreendido como uma experiência carnal e contagiosa, nos excertos extraídos das obras naturalistasrealistas do início do século XX, e, por conseguinte, conceptualizadocategorizado como um vírus que afeta os seres que amam e são amados, tal como acontece com aqueles que são acometidos pelos vírus do ódio e da vingança, em (16):

(15) id=" A bico de pena Prosa: contos CN 1904 realismo masc ": Aquilo foi algum mosquito que a mordeu levando vírus de amor». (OBras).

(16) id="O Tupinambá Prosa: romance SouLim 1931 histórico masc": E, em doses homeopáticas, pequeninas e sucessivas, foi sorvendo o vírus do ódio e da vingança. (OBras). 
Comparando os dados reportados até aqui com o que está registrado em dicionários mais antigos da língua portuguesa, como os dos séculos XVIII e XIX, de autoria dos lexicógrafos Moraes Silva (1789; 1813), Bluteau (1728) e Pinto (1832), foi possível perceber, por exemplo, que o significado etimológico latino "veneno", "peçonha" se mantém nos usos encontrados, mas traz algumas alterações, como a substituição de "veneno" por "matéria peçonhenta de humores quentes", em Moraes Silva (1789; 1813), e "matéria peçonhenta", em Pinto (1832), ou ainda como delimita Bluteau (1728), “(Termo de cirurgia) He hua matéria delgada, fubtil, horrível, feita [...] dos humores quentes".

Entretanto, o fato de não haver, nessas obras lexicográficas, registros dos sentidos metafóricos no século XIX não é uma garantia de que eles não existissem naquele período ou em outros períodos mais recuados da história. Por maior seriedade que haja na organização de um dicionário, nem sempre ele refletirá todas as facetas da complexa rede semasiológica de um item lexical. Isto impede que sejam reveladas outras nuances semânticas que a palavra pode(ria) evocar no contexto de interação entre o sujeito conceptualizador-categorizador-leitor e o texto escrito pela pena dos sujeitos escreventes-poetas-prosadoresconceptualizadores-categorizadores de todos os tempos.

Com base no que foi observado, passo a tecer algumas considerações para concluir esse texto que traz observações e discussões que oportunamente serão retomadas e ampliadas.

\section{CONSIDERAÇÕES FINAIS}

Para finalizar esta etapa do trabalho, sem com isso esgotar ou encerrar a temática estudada nem o manancial de informações a ser obtido, reitero que busquei averiguar a polissemia do item lexical vírus em textos escritos no português brasileiro, entre os séculos XIX, XX e XXI. Como resultado preliminar, concluí que a conceptualização-categorização dos seus diferentes sentidos refletem a intrínseca relação entre os conhecimentos linguístico, cultural e 
enciclopédico dos sujeitos escreventes-leitores-conceptualizadorescategorizadores nos diferentes contextos de uso, ratificando a corporeidade do significado e a complexa teia semasiológica do item lexical estudado, que se manifesta por meio da conservação, variação e mudança dos sentidos encontrados.

Ao cotejar os dados obtidos a partir dos textos escritos no século XXI, com aqueles indicados nos textos dos séculos XIX e XX e nos dicionários consultados, percebi pontos de convergência que evidenciam uma rede de sentidos flexíveis, inter-relacionados entre si e estáveis. Aduzi que a conceptualizaçãocategorização de vírus como um organismo infectocontagioso prevalece nos textos, o que evidencia a sua prototipicidade.

Observei, ainda, que o valor semântico de malware equivalendo a vírus de computador é bastante recorrente a partir do século $X X$, o que me faz crer que seu uso vem se fixando e convencionalizando nos discursos, desde o século passado, de tal modo que parece não haver, na atualidade, outra forma de nomear a circunstância que se manifesta quando uma máquina tem seu sistema operacional corrompido por um corpo (virtual) estranho.

Em síntese, a partir dos dados dos corpora que constituíram o corpus estudado e das metáforas conceptuais e criativas propulsoras da polissemia do item lexical vírus, notei que os seus sentidos mais proeminentes no século XIX podem ser parafraseados como:

- Vírus é um veneno, uma matéria peçonhenta. (Domínio das Ciências Biológicas, que retoma o sentido etimológico e é identificado nos dicionários do século XIX).

- Vírus é um mal ou um valor moral distorcido, nocivo a outrem, que pode afetar negativamente uma população, uma comunidade, um grupo social ou toda a sociedade. (Domínio do Comportamento Social ou da Moralidade). 
Quanto aos séculos XX e XXI, considero que os sentidos encontrados podem ser parafraseados como:

- Vírus é um organismo infeccioso, minúsculo, sem capacidade metabólica, que se replica no interior de células vivas, podendo causar prejuízos à saúde dos seres vivos e contagiar outros. (Domínio da Biologia e/ou das Ciências da Saúde).

- Vírus é um software pernicioso que invade sistemas computacionais, podendo destruir dados, causar prejuízos e alastrar-se por outros arquivos e máquinas. (Domínio das Ciências Computacionais).

- Vírus é um mal ou um valor moral distorcido, nocivo a outrem, que pode afetar negativamente uma população, uma comunidade, um grupo social ou toda a sociedade etc. (Domínio do Comportamento Social e ou da Moralidade, semelhante ao que ocorre no século XIX).

Vale destacar que, mesmo não identificando, no corpus, um sentido positivo para vírus, é possível encontrá-lo em discursos proferidos na contemporaneidade, quando o verbo autoantonímico viralizar, derivado de vírus, é empregado para designar a propagação de uma notícia boa, que alcança um grande número de visualizações, curtidas ou comentários nas redes sociais e repercute positivamente.

Diante disso, espero que, em um futuro próximo, quando a pandemia da COVID-19 provocada pelo novo coronavírus acabar, a perspectivação positiva de vírus possa predominar e todos possam dizer que a vacinação viralizou no planeta e que a felicidade decorrente da saúde é viral a partir de agora.

\section{REFERÊNCIAS}

ALMEIDA, A. A. D. A tessitura do conhecimento: o corpus na construção de estudos semânticos sócio-histórico-cognitivos. In: SOUZA, R.B. et al. (Org.). Filologia em diálogo: descentramentos culturais e epistemológicos. Salvador: Memória e arte, 2020. p. 148-184. 
ALMEIDA, A. A. D. Emergências do léxico, emoção e construção de sentidos: um estudo sobre xerecuda. In: ALMEIDA, A.A.D; SANTOS, E.S.; SIMÕES NETO, N.A. Olhares sobre o léxico: perspectivas de estudos. Salvador: EDUFBA, 2018 p. 27-47.

ALMEIDA, A. A. D. Para aléms de palvras, construções de sentidos no ato de ler: complexidade e cognição. In: BORGES, S. B.; PEREIRA, J. N. (Org.). Língua portuguesa e literatura no livro didático: desafios e perspectivas. Campinas/São paulo: Pontes, 2018, p. 103-123.

ALMEIDA, A. A. D.; SANTANA, N. S. dos. Semântica Cognitiva Sócio-histórica cultural: questões epistemológicas. In: LOPES, N. S.; SANTOS, E. S. Lingua e sociedade: diferentes perspectivas, fim comum. São Paulo: Blucher, 2019p. 113-131.

ALMEIDA, A. A. D.; SANTOS, E. S. dos. Ciência, opinião e Fake News em tempos de coronavírus: conceptualizações em memes sob a abordagem da linguística cognitiva. Pensares em Revista, Rio de Janeiro, n. 19, 2020. Disponível em: - Disponível em: https://www.e-publicacoes.uerj.br/index.php/pensaresemrevista/article/view/52642 Acesso em: 15 ago. de 2020.

ALMEIDA, A. A. D.; SANTOS, E. S. dos. O estudo do significado léxico em semântica sócio-histórica-cognitiva. Macabéa - Revista Eletrônica do Netlli, Cariri, v.8., n.2., - p. 136157, jul.-dez. 2019,

BARCELONA, A. Clarifying and applying the notions of metaphor and metonymy within cognitive linguistics: An update. In: DIRVEN, R.; PÖRINGS, R. (Eds). Metaphor and metonymy in comparison and contrast. Berlin, New York: Mouton de Gruyter, 2003. p. 207-277.

BLUTEAU, R. Vocabulario portuguez, e latino, aulico, anatomico, architectonico, bellico, botanico: autorizado com exemplos dos melhores escritores portuguezes, e latinos; e offerecido a El Rey de Portugal D. Joaõ V. Coimbra, Collegio das Artes da Companhia de Jesus: Lisboa, Officina de Pascoal da Sylva, 1712-1728. 8 v; 2 Suplementos. Disponível em: https://www.bbm.usp.br/pt-br/dicionarios/vocabulario-portuguez-latino-aulicoanatomico-architectonico/ Acesso em: 12 nov. 2020.

BRÉAL, M. Ensaio de Semântica: ciência das significações. Tradução por Aída Ferras et al. São Paulo: EDUC e Pontes, 1992.

CANÇADO, Márcia. Manual de semântica: noções básicas e exercícios. Belo Horizonte: UFMG, 2008.

CUNHA, A. G. da. Dicionário etimológico Nova Fronteira da língua portuguesa. 2ed. rev. acresc. Rio de Janeiro: Nova Fronteira, 1986.

GEERAERTS, D. Cognitive linguistics research: words and other Wonders papers on lexical and sematic Topics. Berlin, New York: Mouton de Gruyter, 2006. 
HAMPE, B.; GRADY, J. (Ed.). From perception to meaning: image schemas in congnitive linguistics. Berlin, New York: Mouton de Gruyter, 2005.

HOUAISS, A.; VILLAR, M. S. Dicionário Houaiss da Língua Portuguesa. Rio de Janeiro: Objetiva, 2019.

JOHNSON, M. The body in the mind. The bodily basis of meaning. Imagination, and reason. Chicago: The University Chicago Presss, 1987.

LAKOFF, G. Women, fire, and dangerous things: what categories reveal about the mind: Chicago and London: The University of Chicago Press, 1987.

LAKOFF, G.; JOHNSON, M. Metáforas da vida cotidiana. Coord. de Tradução. Maria Sophia Zanotto, Campinas, S.P.: Mercado de Letras; São Paulo: EDUC.(Coleção As Faces da Lingüística Aplicada), 2002.

LAKOFF, G.; JOHNSON, M. Metaphors we live by. Chicago: The University of Chicago Press, 1980.

LANGACKER, R. W. Foundations of Cognitive Grammar. Descriptive Application. v.2.Stanford: Stanford Press, 1991.

LINGUATECA. Projeto AC/DC. Disponível em: https: www.linguateca.pt. Acesso em: 10 jan. 2021.

OAKLEY, T. Image schemas. In: GEERAERTS, D.; CUYCKENS, H. (Ed.). The Oxford Handbook of Cognitive Linguistics. New York: Oxford University Press, 2007.

PAIVA, V. L. M. de O. A Metonímia como processo fractal multimodal. Veredas On Line Atemática, Juiz de Fora, v. 01, p. 7-19, 2010. Disponível em: https://www.ufjf.br/revistaveredas/files/2010/08/ARTIGO-1.pdf. Acesso: 11 Nov. 2020.

PINTO, Luiz Maria da Silva. Diccionario da Lingua Brasileira por Luiz Maria da Silva Pinto, natural da Provincia de Goyaz. Na Typographia de Silva, 1832. Disponível em: http://dicionarios.bbm.usp.br/pt-br/dicionario/edicao/3 Acesso: 10 nov. 2020.

SANTOS, E. S. dos. A polissemia na abordagem cognitivista.: um estudo sobre os itens lexicais dar e tomar. In: ALMEIDA, A.A.D; SANTOS, E.S.; SIMÕES NETO, N.A. Olhares sobre o léxico: perspectivas de estudos. Salvador: EDUFBA, 2018. p. 49-68.

SARDINHA, T. B. Metáfora. São Paulo: Parábola, 2007.

SILVA, A. M. Diccionario da lingua portugueza - recompilado dos vocabularios impressos ate agora, e nesta segunda edição novamente emendado e muito acrescentado, por Antonio de Moraes Silva. Lisboa: Typographia Lacerdina, 1789, 1813. Disponível em: http://dicionarios.bbm.usp.br/pt-br/dicionario/edicao/2 Acesso: 10 nov. 2020. 
SILVA, A. S. da. Linguagem, cultura e cognição, ou a lingüística cognitiva. In: SILVA, A. S. da.; TORRES, A.; GOLÇALVES, M. (Org.). Linguagem, cultura e cognição: Estudos de Lingüística Cognitiva. Coimbra: Almedina, 2004. v.4.

SILVA, A. S. da. O mundo dos sentidos em português: polissemia, semântica e cognição. Coimbra: Almedina, 2006.

SILVA, A.S. da. Polissemia e contexto: o problema duro da diferenciação de sentidos. Estudos Linguísticos/Linguistic Studies, 5, Edições Colibri/CLUNL, Lisboa, 2010, pp. 353367.

TALMY, L. How language structures space. In: PICK, H.; ACREDOLO, L. (Ed.). Spatial orientation: theory, research, and aplication. New York: Plenum Press, 1983.

TEIXEIRA, J. Organização conceptual das categorias e a lexicalização de um protótipo (fruta). Diacrítica, Braga, v. 19, n. 1, p. 239-280, 2005. Disponível em: http://repositorium.sdum.uminho.pt/handle/1822/4509 Acesso: 20 nov. 2014.

Nota do editor:

Artigo submetido para avaliação em: 14 de novembro de 2020.

Aprovado em sistema duplo cego em: 15 de fevereiro de 2021. 